DOI: https://doi.org/10.34069/AI/2021.45.09.13

How to Cite:

Romanov, M., Vasylynchuk, V., Grytsyshen, D., Melnyk, O., \& Denysiuk, D. (2021). Organizational and legal framework for the functioning of the National Police investigation units. Amazonia Investiga, 10(45), 120-130. https://doi.org/10.34069/AI/2021.45.09.13

\title{
Organizational and legal framework for the functioning of the National Police investigation units
}

\section{Організаційно-правові засади функціонування підрозділів дізнання Національної поліції України}

Received: August 23, 2021

Abstract

The purpose of the article is a scientific interpretation of the concept, essence and general structure of the organizational and legal framework for the functioning of inquiry units of the National Police of Ukraine and their regulatory support. The subject of the study is the organizational and legal basis for the functioning of inquiry units of the National Police of Ukraine. The research methodology includes the use of general scientific and special methods of scientific cognition: dialectical, logical, normative and dogmatic, logical and semantic, monographic, method of generalization. Research results. The analysis of approaches to understanding the concept and essence of organizational and legal framework for inquiry units of the National Police of Ukraine is carried out. The notion and significance of normative bases, which are focused on providing organizational and legal support for law enforcement agencies in general and inquiry units of the National Police of Ukraine, in particular, are outlined. Practical implication.
Accepted: September 30, 2021

Written by:

Romanov Maksym ${ }^{47}$ https://orcid.org/0000-0003-2443-7744

Vasylynchuk Viktor ${ }^{48}$

https://orcid.org/0000-0001-5415-8450

Grytsyshen Dymytrii ${ }^{49}$

https://orcid.org/0000-0002-1559-2403

Melnyk Oksana ${ }^{50}$

https://orcid.org/0000-0003-1805-830X

Denysiuk Denys ${ }^{51}$

https://orcid.org/0000-0002-9887-9783

\section{Анотація}

Метою статті $\epsilon$ наукове тлумачення поняття, сутності та загальної структури організаційно-правових засад функціонування підрозділів дізнання Національної поліції України та їх нормативного забезпечення. Предметом дослідження $є$ організаційно-правові засади функціонування підрозділів дізнання Національної поліції України. Методологія дослідження включає в себе використання загальнонаукових та спеціальних методів наукового пізнання: діалектичний, логічний, нормативно-догматичний, логікосемантичний, монографічний, метод узагальнення. Результати дослідження. Проведено аналіз підходів до розуміння поняття та сутності організаційно-правових засад функціонування підрозділів дізнання Національної поліції України. Окреслено поняття та значення нормативних підстав, що орієнтовані на забезпечення організаційноправових засад загалом і підрозділів дізнання Національної поліції України, зокрема.

\footnotetext{
${ }^{47}$ Senior Research Fellow of Public Law Problems Research Department of the Scientific Institute of Public Law, Ukraine.

${ }^{48}$ Doctor of Law, Professor, Professor of the Department of Operational and Investigative Activities of the National Academy of Internal Affairs, Ukraine.

${ }^{49}$ Doctor of Economics, Doctor of Public Administration Sciences, Professor, Dean of the Faculty of Public Administration and Law of Zhytomyr Polytechnic State University, Ukraine.

${ }^{50} \mathrm{PhD}$ in Law, Associate Professor, Associate Professor of Criminal Procedure Department of the National Academy of Internal Affairs, Ukraine.

${ }^{51} \mathrm{PhD}$ in Law, Associate Professor, Leading Researcher of the Scientific Institute of Public Law, Ukraine.
} 


\section{AMAZONIA
Drvestiga}

The significance and elements of organizational and legal framework in the context of sustainable and stable functioning of inquiry units of the National Police of Ukraine are clarified. Value / originality. The problems are outlined and recommendations for their possible solution and improvement of the relevant institution are developed.

Key words: principles of functioning, regulatory framework, supervision, inquiry, connoisseur.

\section{Introduction}

The Constitution and laws of Ukraine regulate the chosen European integration course of the State. The vector of pro-European development of Ukraine and its citizens was chosen not by chance, because only such a way allows to reliably strengthen the functioning of the institution of human and civil rights and freedoms in a view of democratic values.

Our country has a wide range of law enforcement agencies, one of the main tasks of which is to ensure proper observance of human and civil rights and freedoms, investigation of criminal offenses and prosecution of perpetrators. However, given the large of criminal acts, the issue of their investigation needs and has always required differentiation.

The essence of this process is the distribution of powers between various public authorities to protect the rights and freedoms of an individual and citizen through investigating criminal offenses of various kinds. One of such bodies is the National Police of Ukraine, which conducts pre-trial investigation of criminal offenses under their jurisdiction, which constitute about $92 \%$ of the articles of the Criminal Code of Ukraine (Law of Ukraine No. 2341-III, 2001).

The institution of inquiry units of the National Police of Ukraine was introduced in order to relieve the pre-trial investigation bodies (namely, investigators of the National Police of Ukraine). The activities of inquiry units is regulated by a number of normative and legal acts, which determine their bases of organization, direction of activity and separate elements of the mechanism of functioning. However, the issues of organizing the work of the relevant departments, regulatory and legal support of their organizational and legal foundations and fundamental aspects of the functioning generally remain open.
Практичне значення. 3'ясувано значення та елементів організаційно-правових засад у контексті сталого та стабільного функціонування підрозділів дізнання Національної поліції України. Цінність/оригінальність. Окреслено проблеми та розроблено рекомендації щодо можливого їх розв'язання та вдосконалення відповідного інституту.

Ключові слова: засади функціонування, нормативні основи, нагляд, дізнання, дізнавач.

Thus, the aim of the article is scientific interpretation of the concept, nature and general structure of organizational and legal framework of the National Police of Ukraine in general and inquiry units in particular on the basis of the views of scientists, current regulations and statistics.

\section{Methodology}

The process of cognition, as the basis of any scientific research, is quite complex and requires a conceptual approach based on a certain methodology, the application of certain methods. The method is a tool for solving the main task of science - the discovery of objective laws of reality. The method determines the need and place of application of induction and deduction, analysis and synthesis, abstraction, formalization, modeling, etc. The specifics of our research have led to the choice of the following methods.

Dialectical method helps to analyze the approaches to understanding the concept and essence of the organizational and legal framework for the functioning of the inquiry units of the National Police of Ukraine.

Using logical method, the concept and meaning of normative basis, which is focused on providing organizational and legal support for inquiry units of the National Police of Ukraine, are outlined.

Normative and dogmatic method is applied in the study of normative acts that regulate the issues of the concept, nature and general structure organizational and legal bases of the functioning of inquiry units of the National Police of Ukraine.

System and structural method is useful in creating legal framework for the functioning of 
inquiry divisions of the National Police of Ukraine, as well as for the determination of the main functions of inquiry units, which are enshrined in the relevant organizational and legal framework.

Logical and semantic method makes it possible to examine the concept of organizational and legal foundations of the functioning of the relevant police units.

Monographic method is used in the investigation of the views of scientists who have considered the issue under consideration.

Method of generalization helps to develop recommendations for possible solutions to the outlined problems and improve the relevant institution.

\section{Literature Review}

According to a number of scholars, organizational and legal framework for law is the starting point that legally fixes the objective laws of social development (Bespalko 2018, p. 53). Pursuant to Geneva Centre for the Democratic Control (DCAF, 2015, p. 7) legal framework in police activities is: constitutional and organic laws, policies and plans conform to national and international law.

In turn, the scholars who study the issues of organizational and legal support for public authorities pay attention to some special features of this category.

For example, Pryimachenko (2013, p. 60) argues that the organizational support of the judiciary is a set of administrative, financial, informational, organizational and logistical measures of influence implemented by the State Judicial Administration of non-procedural nature, which are aimed at creating and maintaining appropriate conditions for the effective functioning of the judiciary.

Studying the organizational support of the Prosecutor's Office, Shahanenko (2015, p. 146), proposes to supplement the already reasoned list of features of the organizational support with: personnel measures (which, in our opinion, are absorbed by the administrative measures described by the abovementioned authors); informational and operational measures (which act as a narrow reflection of the previously mentioned informational and organizational measures).
In our opinion, Zabroda (2013, p. 47) provides the most comprehensive and complete research on the essence of organizational and legal measures. He states that organizational and legal framework includes: 1) mandatory elements (legal basis (legislation); object of legal regulation; priority areas; principles; actors and their tasks, functions and powers, means (measures and methods), by which the public relations are regulated (including responsibilities and mechanisms of control and supervision) and 2) optional elements (organization of international cooperation) in the relevant area; information support; specifics of funding; features of interaction and coordination in a particular area.

Piotrowski et al. (2021) prove that there is a positive influence of organizational support and organizational justice on the work of a police officer. To substantiate this view, they have studied the relevant data and performed correlation analyses.

Boateng (2014) having studied the issue of organizational Support and police officer effectiveness, states that it has received considerable attention in the academic literature, but a little scholarly attention in police circles. To solve this problem, the scientist presents the relevant survey results on the officers' perception of organizational support influence on the effectiveness in performing assigned duties.

\section{Results and Discussion}

The urgency of the topic is due to Ukraine's European integration efforts, which at the present stage of the State formation are implemented in a way to strengthen the institution of democracy and the rule of law as a basis for public authorities and local government.

One of the most comprehensive and effective steps to reform criminal justice and the structure of law enforcement agencies in the context of optimizing their work was the establishment of a system of inquiry units of the National Police of Ukraine.

One of the mandatory elements of the organizational and legal framework for the functioning of the investigation units of the National Police of Ukraine is the relevant regulatory framework.

Regulatory legal support is legal mechanisms that are enshrined at the national level, which are binding and compulsory and consist of national 


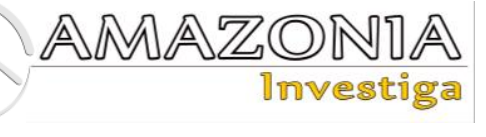

laws and regulations, contractual obligations (Geneva Centre for Security Sector Governance, 2021).

The normative bases for the functioning of inquiry divisions of the National Police of Ukraine consist of:

1. The Constitution of Ukraine (Law of Ukraine No. 254k/96-VR, 1996), which defines the basic provisions of respect for human and civil rights and freedoms, restrictions on law enforcement in terms of influencing human and civil rights and freedoms in criminal proceedings.

2. The Criminal Procedure Code of Ukraine (Law of Ukraine No. 4651-VI, 2012), which partially covers the basics of organizational and legal nature in relation to the inquiry units of the National Police of Ukraine;

3. Law of Ukraine "On the National Police" (Law of Ukraine No. 580-VIII, 2015), which establishes the profound organizational and legal and constitutive principles, tasks, and algorithms of the National Police of Ukraine as the central body of State power authorized to prevent and combat crime in general and investigating criminal offenses in particular.

4. Law of Ukraine "On the Disciplinary Statute of the National Police" (Law of Ukraine No. 2337-VIII, 2018), which defines the general procedure for disciplinary proceedings against police officers of the National Police of Ukraine.

5. Law of Ukraine "On Amendments to Certain Legislative Acts of Ukraine on Simplification of Pre-trial Investigation of Certain Categories of Criminal Offenses" (Law of Ukraine No. 2617-VIII), which is the main organizational and legal basis for pre-trial investigation of criminal offenses by the inquirers and investigators of the National Police of Ukraine.

6. Regulation on the organization of the activities of inquiry units of the National Police of Ukraine (Order of the Ministry of Internal Affairs of Ukraine 2020, No. 405), which defines the basic organizational and legal principles of functioning of inquiry units.

Organizational and legal bases for the functioning of inquiry units of the National Police of Ukraine also consist of priority directions and principles.

There is no clear definition of the concept of direction in jurisprudence, however, its essence is reflected in part in philosophical categories, such as the concept of progress.

Scientists emphasize that the progress is based on increasing the level of organization, which is manifested in the ability to self-organization, self-regulation, self-management in the most highly organized forms of matter (Shynkaruk 1986 , p. 539 - 540).

Therefore, when interpreting the concept of direction through the definition of progress, it should be noted that in the context of organizational and legal framework for the National Police of Ukraine, the direction is a vector of gradual movement towards progress or regress, characterized by self-organization, selfregulation and self-management.

The concept of task is also reflected in reference sources and is interpreted as a predetermined, planned amount of work, business or goal to which they aspire; what they want to achieve (Kunch 2005). According to the current legislation, the tasks of the National Police of Ukraine (Law of Ukraine No. 580-VIII, 2015) are to provide police services in the following areas:

ensuring public safety and order (which can be implemented by the staff of the inquiry unit as a result of preventive actions and encouraging individuals and citizens not to violate public order and safety);

protection of human rights and freedoms, as well as the interests of society and the State (which is fully realized in the main functions of the National Police of Ukraine: pre-trial investigation of criminal offenses, prosecution of perpetrators, protection and defense of the rights and freedoms of victims, suspects and others involved in pre-trial investigation);

combating crime (which is fully reflected in the functions of the inquiry units and is implemented in their daily activities connected with pre-trial investigation of criminal offenses, which aims, in particular, to bring the perpetrators to justice); providing, within the limits prescribed by law, assistance to persons who need it because of personal, economic, social reasons or as a result of emergencies (which is reflected in the inquirers' non-procedural activities, as the official is also a police officer with general duties as a law enforcement officer, including providing assistance to people).

Turning back to the principles, we can state that they are basic, original ideas, characterized by universality, general significance, higher 
imperative and reflect the essential provisions of theory, doctrine, science, domestic and international law, political, State or community organizations (humanism, legality, justice, equality of citizens before the law, etc.) (Skakun 2001, p. 258).

In turn, having considered these approaches to the interpretation of the concept of principles in law, it is necessary to investigate the issue of their interpretation taking into account the views of scientists and the principles of the National Police of Ukraine defined by the current legislation of Ukraine.

Kolodii (2012), considering the classification of the principles of law, notes that the general principles of law are universal, and specifically embodied in the principles of each area of law; the autonomous principles of lawmaking are embodied in law enforcement. The author emphasizes that the basic principles are divided into general and social and specific and legal (systemic and structural); among general and social one can highlight political, economic, social, ideological, moral foundations of law.

Thus, the author affirms the existence of the following structure: 1) the principles of the legal system: a) common law (basic) principles; b) intersectoral principles; c) sectoral principles; d) the principles of legal institutions.

At the same time, applying the obtained theoretical results to practical activities and the legal basis for the functioning of law enforcement agencies, the principles of the National Police of Ukraine are:

rule of law (which is a basic and fundamental principle that directs the work of the agency solely in the interests of human and civil rights and freedoms defined not only by the Constitution of Ukraine and current international agreements, which the Verkhovna Rada of Ukraine agreed to be bound by, but also by the Criminal Procedure Code of Ukraine and the Law of Ukraine "On the National Police"); observance of human rights and freedoms (which lies not only in their protection during conducting organizational, official or procedural activities, but also in showing respect in other situations of official nature (while on duty, in public places, etc.);

legality (which directs the work of the inquiry unit and its officials only in the manner and within the limits provided by applicable law);

transparency (which means providing information to the authorities and the public by inquiry units about their activities in the area of protection of human rights and freedoms, crime prevention, public safety and order, as well as access to public information owned by the National Police of Ukraine in the manner and in accordance with the requirements specified by law);

political neutrality (which is to ensure the protection of human and civil rights and freedoms, regardless of political beliefs and party affiliation);

interaction with the population on the basis of partnership (which means cooperation and interaction with the population in its various forms (involvement of the public concerned in the conduct of investigation (search) as witnesses or as extras);

continuity (which means continuous and roundthe-clock performance of tasks by the inquiry units of the National Police of Ukraine within the limits and in the manner prescribed by the Criminal Procedure Code) and is reflected in the right of an individual to seek help from the police or police officers.

Subjects, their tasks, functions and powers are another essential element of the organizational and legal framework for the functioning of inquiry units of the National Police of Ukraine.

The subjects of the inquiry units of the National Police of Ukraine are their structural elements (organizational and staffing units), which include: the Inquiry Department of the National Police of Ukraine; departments (sectors) of inquiry of the Main Directorates of the National Police; departments (sectors) of inquiry of territorial (separate) police units; investigators, as well as police officers of other units of the National Police of Ukraine, who are authorized to conduct pre-trial investigation of criminal offenses.

The tasks of these subjects are:

protection of the individual, society and the State from criminal offenses (which lies in the implementation of a prompt, complete and impartial pre-trial investigation of criminal offenses in compliance with all legal procedures and objective factors);

protection of the rights, freedoms and legitimate interests of participants in criminal proceedings (which is to respect the rights and freedoms of all participants in criminal proceedings and protect them from encroachment;

ensuring prompt, full and impartial investigation of criminal offenses under the jurisdiction of the National Police of Ukraine (which lies in the 


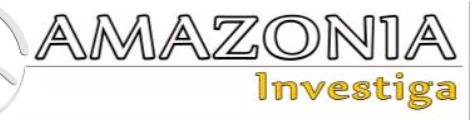

implementation of the principle of inevitability of liability for offenses and compliance with pretrial investigation. The completeness of the investigation and disclosure of a criminal offense depend on how quickly the procedural actions are carried out, which will help to protect the legitimate interests of persons involved in criminal proceedings; completeness means that all circumstances to be proved in criminal proceedings are established. In this regard Shcherbakovskyi et al (2020, p. 123) note that errors and violations that take place at the stage of pre-trial investigation lead to the restriction of human rights and freedoms;

ensuring compensation to individuals and legal entities for damage caused by criminal offenses (lies in the most effective implementation of criminal procedural and administrative tools by the inquirer to legally achieve the goals and objectives of pre-trial investigation and creating appropriate grounds for further compensation to individuals and legal entities for damage caused by criminal offenses);

identifying the causes and conditions that contribute to the commission of criminal offenses, and taking measures to eliminate them.

Besides, the main functions of inquiry units are:

the analysis of the practice of pre-trial investigation of criminal offenses, organization and results of the activities of the inquirers, and making proposals for efficiency gains (which can be implemented through systematic individual evaluation of inquirers, by rating, taking into account all objective, subjective factors); use of means to improve the quality of the inquiry and compliance with its deadlines;

study, generalization of positive experience of inquiry, its introduction into the practice of inquiry units, development of modern methods of investigation of certain types of criminal offenses (which is expressed in borrowing international experience of units conducting pre-trial investigation of criminal offenses);

organization of interaction of inquiry units with other units of the National Police, investigators and detectives of other law enforcement agencies, entities engaged in forensic activities, units engaged in operational and investigative activities, as well as prosecutors, who supervise compliance with the law during pre-trial investigation in the form of procedural guidance of pre-trial investigation (carried out directly by the inquirer in the pre-trial investigation, by drawing up procedural documents);

studying the practice of application of legal norms by inquirers and development of proposals to improve the legislation of Ukraine (which is reflected in the creation of high quality methodological support for inquiry units of the National Police of Ukraine, formed using the practice of application of legal norms, statistics); ensuring selection, placement and education of personnel for inquiry units, improving their skills and professionalism (which serves as a basis for further development of the inquiry institution in Ukraine as a body authorized to investigate criminal offenses and is reflected in the development of training programs, training courses qualifications and professional skills, as well as trainings, seminars, workshops and the creation of other formats and algorithms for the training of inquirers and persons authorized for inquiry in the National Police of Ukraine); addressing and adjudicating on citizens' appeals received in relation to the inquiries.

The powers, in contrast to the tasks and functions, are defined only for a few categories of inquirers, namely for the Head of the Inquiry Department of the National Police of Ukraine; Head of the Main Directorate of the National Police Inquiry Department (sector); Head of the Department (sector) of Inquiry of the Territorial Police Unit. In turn, these powers are generally formulated almost identically, duplicating and differentiating depending on the level of administrative importance of the post occupied by the relevant manager.

One of the most important elements of the organizational and legal framework for the functioning of any public authority is the mechanisms of responsibility and control, supervision of specific activities.

The most accurate in the context of the need to define the concept of responsibility of the inquirer as an official of the police and the procedural person carrying out pre-trial proceedings is the consideration of existing scientific provisions on the interpretation of the relevant category.

Legal liability arises precisely because the subject of the offense is in a general relationship of responsibility with the State, but breaks this connection by an act of irresponsible behavior. This statement most accurately and clearly reflects the essence of the responsibility of the inquirer - the violation of previously assumed legal obligations, for which there is a necessary and inevitable legal consequence.

In order to prosecute officials of the National Police of Ukraine and persons authorized to conduct pre-trial investigations of criminal 
offenses, there is a system of bodies and legal bases for their activities in order to exercise appropriate control and supervision.

The scientists emphasize that the control function not only provides legality, compliance with mandatory requirements, but also involves conducting the test to ensure that the legal model is met, as well as analysis of the actual state of implementation of the rules of conduct, the results obtained (Horbova 2019, p. 39).

The control over the activities of employees of inquiry units in the system of the National Police of Ukraine in terms of compliance with discipline and legality is most effectively performed by the Personnel Inspection Department of the Personnel Department of the National Police of Ukraine.

The main reason for prosecuting a police officer is the violation of official discipline, which is expressed in non-compliance with the Disciplinary Statute of the National Police of Ukraine, which defines the essence of official discipline in the National Police of Ukraine, the powers of police officers and their superiors, the procedure for their application and appeal.

The observance of official discipline, in accordance with the Disciplinary Statute, is based on the creation of the necessary organizational and socio-economic conditions for honest, impartial and dignified performance of police duties, respect for the honor and dignity of police officers, education of conscientious attitude to police duties by the prudent application of methods of persuasion, encouragement and coercion.

It should be noted that bringing an inquirer to disciplinary responsibility is possible only for the act that violates the principles of discipline and legality in the activities of the National Police of Ukraine, as there is a separate mechanism for appealing procedural decisions, actions or omissions in the criminal process associated with procedural supervision.

At the same time, it should be emphasized that there is the concept of judicial control in the system of criminal proceedings, which is a direct part of the normative component of the organizational and legal framework for the operation of inquiry units of the National Police of Ukraine.

Judicial practice indicates that judicial control over the procedural actions and decisions of the inquirer is an extremely effective and efficient means of protecting legal rights and interests of participants in criminal proceedings. The function of judicial control in the domestic criminal procedural legislation during the pretrial investigation is entrusted to a new subject in the criminal process - the investigating judge (Kyslenko 2015, p. 178).

The concept of supervision is interpreted in many ways. The meaning of the term "supervision" is often revealed through the concept of "control". In this regard Busel (2005, p. 992) emphasizes that the meaning of these words is the same in the conventional sense.

However, it should be emphasized that the essence of these definitions is clearly distinguished by the subject of the relevant authority in relation to the supervision over the activities of inquiry units of the National Police of Ukraine. Supervision in this case is the function of the prosecutor's office under current law; control is attributed to the powers of the inspection of the personnel of the National Police of Ukraine, and in terms of the exercise of procedural powers it is empowered to the functions of the court, the investigating judge. In any case, these elements are part of the organizational and legal framework for the operation of inquiry units of the National Police of Ukraine.

It should also be emphasized that in the context of globalization, mutual and systematic exchange of experience between law enforcement agencies around the world, the issue of international cooperation as an element of organizational and legal framework and one of the priorities of the latter is very important for sustainable development.

Etymologically, the term "cooperation" means joint activities, participation, partnership, interaction (Khomaiko 2018, p. 70). The researcher Kuznetsov and Tuzmukhamedov (2010, p. 207) believe that international cooperation is a joint action of the actors in any area of their common interests, interconnected activities to coordinate their views, actions, solve problems that have mutual significance for the adoption of mutually acceptable decisions.

Information and analytical support as an element of organizational and legal bases of functioning of inquiry units of the National Police of Ukraine is the most important optional direction from the point of view of rapid information progress of society. 


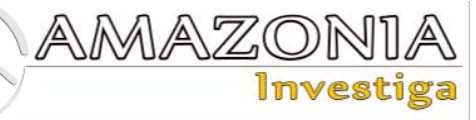

Regarding the concept of information and analytical support in the scientific space, there is a certain discussion, which is expressed in the controversial attribution of a number of features to this category.

Thus, according to Hlushkov (1973), the structure of information and analytical activities should include information support, information and analytical work, databases, including information retrieval, goals, motives, methods and techniques of their implementation. It should be noted that information and analytical activity is a product of intellectual, creative general civilization tendencies that characterize the development of mankind aimed at the formation of priorities for sustainable development of civilization and informatization (Zakharova and Filipova 2013).

It is appropriate to note that the National Police of Ukraine performs the following actions within information and analytical support: forms databases (banks) that are part of a single information system of the Ministry of Internal Affairs of Ukraine; carries out information retrieval and information and analytical work; uses databases (banks) of the Ministry of Internal Affairs of Ukraine and other public authorities.

We stress on the need to use the full range of information and analytical technologies in the activities of inquiry units, as it is necessary not only for the development, but also for the normal exercise of powers given the annual number of registered criminal offenses, rapid informatization of all spheres of public administration and social life, as well as improving digital literacy.

\section{Conclusion}

Thus, we analyzed the most important, in our opinion, and essential elements of the organizational and legal framework for the operation of inquiry units of the National Police of Ukraine.

Therefore, on the basis of the analyzed approaches to understanding the concept of organizational and legal principles and regulatory support, highlighting their essence and research approaches to understanding the structural elements and essence, we have made the following conclusions:

1. Organizational and legal principles of functioning are, in their general sense, original and legally fixed patterns of organization and streamlining the processes of ensuring the proper operation or functioning of anything.

2. Organizational and legal bases for the functioning of inquiry units of the National Police of Ukraine are normatively fixed initial laws of administrative, material, financial or any other nature in relation to the organization and streamlining the processes of maintenance of proper functioning of the corresponding institution.

3. The essence of the organizational and legal basis for the functioning of the inquiry units of the National Police of Ukraine is their importance for the development and expansion of opportunities for the implementation of the functions assigned to the relevant agencies. In turn, the structure of organizational and legal framework for the activity (functioning) is rather extensive and includes both mandatory and optional elements.

4. Normative support is the legal mechanisms established by the State as obligatory and compulsory for all individuals who are in its territory (except for the cases defined by law), consisting of national laws and other regulatory legal acts (acts of the President of Ukraine, resolutions of the Verkhovna Rada of Ukraine, resolutions and orders of the Cabinet of Ministers of Ukraine, other normative, organizational and administrative documents adopted in the manner prescribed by law).

5. The list of normative legal acts that ensure the functioning and organizational and legal support includes: the Constitution of Ukraine, the Criminal Procedure Code of Ukraine, the Law of Ukraine "On the National Police", the Law of Ukraine "On the Disciplinary Statute of the National Police", the Law of Ukraine "On the amendments to some legislative acts of Ukraine to simplify the pre-trial investigation of certain categories of criminal offenses", Regulation on the organization of the activities of inquiry units of the National Police of Ukraine.

6. The mandatory elements of the organizational and legal framework for the operation of inquiry units of the National Police of Ukraine are:

6.1. Normative basis (in general: the Law of Ukraine "On the National Police", the Law of Ukraine "On the Disciplinary Statute of the National Police", Regulation on the organization of inquiry units of the National Police of Ukraine; in particular: Criminal Procedure Code of Ukraine, the Law of 
Ukraine "On Amendments to Certain Legislative Acts of Ukraine on Simplification of Pre-trial Investigation of Certain Categories of Criminal Offenses", other normative and legal acts);

6.2. Subjects and their tasks, functions and powers (i.e. the activities in the system of law enforcement agencies of Ukraine of inquiry units as an institution authorized for pre-trial investigation of criminal offenses);

6.3. Priority areas, principles, which in this case are determined by the general principles of the National Police of Ukraine (public safety and order; protection of human rights and freedoms, as well as the interests of society and the State; crime prevention; providing assistance to persons who are in need) and by the basic principles (rule of law; respect for human rights and freedoms; legality; transparency; political neutrality; interaction with the population on the basis of partnership; continuity).

6.4. The mechanisms of responsibility and control, supervision of specific activities (for example, management of the inspection of personnel of the National Police of Ukraine (at the general level), and also the bodies of the prosecutor's office and the court (in matters of purely procedural activities and the need to respect the rights and freedoms of all participants in criminal proceedings).

7. Besides, the optional elements of the organizational and legal framework for the operation of inquiry units of the National Police of Ukraine consist of:

7.1. Organization of international cooperation, which lies in both organizational and procedural assistance in preventing the commission of criminal offenses by individuals and the establishment of a system of joint exercises for mutual exchange of experience, methods of training and retraining of other police officers to work in inquiry units;

7.2. Organization of information and analytical support as the system of training (retraining) of specialists for inquiry units using the latest information technologies and the use of various innovations (electronic databases, information and reference Internet resources, etc.) in the investigation of criminal offenses;

The prospect for the further scientific research is, first of all, to expand a certain scientific position, its argumentation taking into account the views of a wider range of scientists, regulations of national and international jurisdiction, as well as experience in determining the organizational and legal framework of pre-trial investigation of criminal offenses.

\section{Bibliographic references}

Bespalko, I. (2018). Definition of the concept of general principles of criminal proceedings. Enterprise, Economy and Law, No. 5, pp. 242-247. http://pgpjournal.kiev.ua/archive/2018/5/48.pdf

Boateng, F. (2014). Perceived Organizational Support and Police Officer Effectiveness: Testing the Organizational Support Theory in Ghana. International Criminal Justice Review, 24. 10.1177/1057567714536907.

Busel, V. (2005). Large explanatory dictionary of modern Ukrainian language. Kyiv, Irpin: Perun.

Geneva Center for Security Sector Governance (DCAF) (2015). The police: roles and responsibilities in good security sector governance.

https://www.dcaf.ch/sites/default/files/public ations/documents/DCAF_BG_7_The\%20Pol ice.pdf

Geneva Center for Security Sector Governance (DCAF) (2021). Regulatory and legal support. URL: https://securitysectorintegrity.com/uk/\%d1\% $81 \% \mathrm{~d} 1 \% 82 \% \mathrm{~d} 0 \% \mathrm{~b} 0 \% \mathrm{~d} 0 \%$ bd\%d0\%b4\%d0 $\%$ b0\%d1\%80\%d1\%82\%d0\%b8-\%d1\%96$\% \mathrm{~d} 0 \%$ bd $\% \mathrm{~d} 0 \% \mathrm{~b} 0 \% \mathrm{~d} 1 \% 81 \% \mathrm{~d} 1 \% 82 \% \mathrm{~d} 0 \% \mathrm{~b}$ $0 \% \mathrm{~d} 0 \%$ bd $\%$ d0\%be $\% \mathrm{~d} 0 \%$ b2\%d0\%b8/\%d0\% bd\%d0\%be \%d1\%80\%d0\%bc\%d0\%b0\%d1 $\% 82 \%$ d0\%b8\%d0\%b2\%d0\%bd\%d0\%be$\% \mathrm{~d} 0 \%$ bf\%d1\%80\%d0\%b0\%d0\%b2\%d0\%b e\%d0\%b2\%d0\%b5-

$\% \mathrm{~d} 0 \% \mathrm{~b} 7 \% \mathrm{~d} 0 \% \mathrm{~b} 0 \% \mathrm{~d} 0 \% \mathrm{~b} 1 \% \mathrm{~d} 0 \% \mathrm{~b} 5 \% \mathrm{~d} 0 \% \mathrm{~b}$ $7 \% \mathrm{~d} 0 \% \mathrm{bf} \% \mathrm{~d} 0 \% \mathrm{~b} 5 \% \mathrm{~d} 1 \% 87 \% \mathrm{~d} 0 \% \mathrm{~b} 5 \% \mathrm{~d} 0 \%$ bd $\%$ d0\% bd\%d1\%8f/

Hlushkov, V. (1973). Encyclopedia of Cybernetics, Vol. 2 (M-Ya). Kyiv: Main Editorial Board of the Ukrainian Soviet Encyclopedia.

https://cyberua.info/novyny/pershaencyklopedija-kibernetyky-2t-ukr-redvhlushkov-1973/

Horbova, N. (2019). The nature of State control (supervision) and the genesis of its legislative definition. Law and Public Administration, 1, 1(34), pp. $37-42$

Khomaiko, K. (2018). Cooperation of public authorities with international organizations: scientific discourse. Public Administration and Local Self-Government, No. 4, pp. $66-74$. 


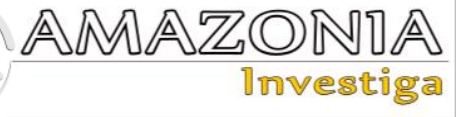

Kolodii, A. (2012). Principles of law: genesis, concept, classification and implementation. Almanac of Law, No. 3, pp. $42-46$. http://dspace.nbuv.gov.ua/bitstream/handle/1 23456789/63807/08-

Kolodiy.pdf?sequence $=1$ cept, $\% 20$ classificati on $\% 20$ and $\% 20$ implementation

Kunch, Z. (2005). Universal dictionary of the Ukrainian language. Ternopil: Educational Book-Bohdan.

Kuznetsov, V. and Tuzmukhamedov, B. (2010). International law: a textbook. Moskow: Norma, Infra-M. http://oceanlaw.ru/wpcontent/uploads/2017/10/\%D0\%9A\%D1\%8 3\%D0\%B7\%D0\%BD\%D0\%B5\%D1\%86\% D0\%BE\%D0\%B2-\%D0\%92.\%D0\%98.$\% \mathrm{D} 0 \% \mathrm{~A} 2 \% \mathrm{D} 1 \% 83 \% \mathrm{D} 0 \% \mathrm{~B} 7 \% \mathrm{D} 0 \% \mathrm{BC} \% \mathrm{D}$ $1 \% 83 \% \mathrm{D} 1 \% 85 \% \mathrm{D} 0 \% \mathrm{~B} 0 \% \mathrm{D} 0 \% \mathrm{BC} \% \mathrm{D} 0 \% \mathrm{~B}$ $5 \% \mathrm{D} 0 \% \mathrm{~B} 4 \% \mathrm{D} 0 \% \mathrm{BE} \% \mathrm{D} 0 \% \mathrm{~B} 2-$

$\% \mathrm{D} 0 \% 91 . \% \mathrm{D} 0 \% \mathrm{~A} 0 .-$

$\% \mathrm{D} 0 \% 9 \mathrm{C} \% \mathrm{D} 0 \% \mathrm{~B} 5 \% \mathrm{D} 0 \% \mathrm{~B} 6 \% \mathrm{D} 0 \% \mathrm{~B} 4 \% \mathrm{D}$ $1 \% 83 \% \mathrm{D} 0 \% \mathrm{BD} \% \mathrm{D} 0 \% \mathrm{~B} 0 \% \mathrm{D} 1 \% 80 \% \mathrm{D} 0 \%$ $\mathrm{BE} \% \mathrm{D} 0 \% \mathrm{~B} 4 \% \mathrm{D} 0 \% \mathrm{BD} \% \mathrm{D} 0 \% \mathrm{BE} \% \mathrm{D} 0 \% \mathrm{~B} 5$

$\% \mathrm{D} 0 \% \mathrm{BF} \% \mathrm{D} 1 \% 80 \% \mathrm{D} 0 \% \mathrm{~B} 0 \% \mathrm{D} 0 \% \mathrm{~B} 2 \% \mathrm{D}$ 0\%BE-3-\%D0\%B5\%D0\%B8\%D0\%B7\%D0\%B4.-2010.pdf

Kyslenko, D. (2015). The concept and essence of judicial control during the pre-trial investigation. Legal Science. Series: Criminal Procedure Law, Criminology, No. 7, pp. 176 - 184.

Law of Ukraine No. 254k/96-VR. Constitution of Ukraine. Official Web site of the Verkhovna Rada of Ukraine, June 28, 1996. Available online.

https://zakon.rada.gov.ua/laws/show/254\%D 0\%BA/96-\%D0\%B2\%D1\%80\#Text

Law of Ukraine No. 2341-III. Criminal Codex of Ukraine. Official Web site of the Verkhovna Rada of Ukraine, April 05, 2001. Available online,

https://zakon.rada.gov.ua/laws/show/234114\#Text

Law of Ukraine No. 4651-VI. Criminal Procedure Code of Ukraine. Official Web site of the Verkhovna Rada of Ukraine, April 13, 2012. Available online. https://zakon.rada.gov.ua/laws/show/465117\#Text

Law of Ukraine No. 580-VIII. About the National Police. Official Web site of the Verkhovna Rada of Ukraine, July 02, 2015. Available online.

https://zakon.rada.gov.ua/laws/show/58019\#Text

Law of Ukraine No. 2337-VIII. On the disciplinary status of the National Police of Ukraine. Official Web site of the
Verkhovna Rada of Ukraine, March 15, 2018. Available online.

https://zakon.rada.gov.ua/laws/show/233719\#Text

Law of Ukraine No. 2617-VIII. On the amendment of some legislative acts of Ukraine concerning the simplification of the preliminary investigation of different categories of criminal offenses. Official Web site of the Verkhovna Rada of Ukraine, November 22, 2018. Available online. In: https://zakon.rada.gov.ua/laws/show/261719\#Text

Order of the Ministry of Internal Affairs of Ukraine No. 405. On the statement of the Situation on the organization of the activity of the investigative divisions of the organs of the National Police of Ukraine. Official Web site of the Verkhovna Rada of Ukraine, May 20, 2020. Available online. In: https://zakon.rada.gov.ua/laws/show/z049120\#Text

Piotrowski, A., Rawat, S. and Boe, O. (2021) Effects of Organizational Support and Organizational Justice on Police Officers' Work Engagement. Front. Psychol, Vol 12, 642155. Doi: 10.3389/fpsyg.2021.642155

Pryimachenko, D., and Ihonin, R. (2013). The ratio of the concepts of "organizational support of courts", "organizational management in courts" and "judicial management. Word of the National School of Judges of Ukraine, No. 1, pp. 57 - 66. http://biblio.umsf.dp.ua/jspui/bitstream/1234 56789/1946/1/\%D0\%9F\%D1\%80\%D0\%B8 $\% \mathrm{D} 0 \% \mathrm{~B} 9 \% \mathrm{D} 0 \% \mathrm{BC} \% \mathrm{D} 0 \% \mathrm{~B} 0 \% \mathrm{D} 1 \% 87 \% \mathrm{D}$ $0 \% \mathrm{~B} 5 \% \mathrm{D} 0 \% \mathrm{BD} \% \mathrm{D} 0 \% \mathrm{BA} \% \mathrm{D} 0 \% \mathrm{BE} \% 20 \%$ D0\%86\%D0\%B3\%D0\%BE\%D0\%BD\%D1 \%96\%D0\%BD\%202013_1_9.pdf

Shahanenko, P. (2015). The concept of organizational support for the Prosecutor's Office. Journal of Kyiv University of Law, No. 4, pp. $144 \quad-\quad 147$. http://webcache.googleusercontent.com/sear ch?q=cache:V85KF5bhVzAJ:irbis-

nbuv.gov.ua/cgi-

bin/irbis_nbuv/cgiirbis_64.exe\%3FC21CO M\%3D2\%26I21DBN\%3DUJRN\%26P21DB N\%3DUJRN\%26IMAGE_FILE_DOWNLO AD\%3D1\%26Image_file_name\%3DPDF/C hkup_2015_4_33.pdf+\&cd=2\&hl=ru\&ct=cl $\mathrm{nk} \& \mathrm{gl}=\mathrm{ua}$

Shcherbakovskyi, M., Stepaniuk, R., Kikinchuk, V., Oderiy, O., \& Svyrydova, L. (2020). Evidentiary problems in the investigation of corruption crimes in Ukraine. Amazonia Investiga, 9(32), pp. 117124.

https://doi.org/10.34069/AI/2020.32.08.12 
https://amazoniainvestiga.info/index.php/am azonia/article/view/1481/1425

Shynkaruk, V. (2002). Philosophical Encyclopedic Dictionary. Kyiv: Abrys. https://shron1.chtyvo.org.ua/Shynkaruk_Vol odymyr/Filosofskyi_entsyklopedychnyi_slo vnyk.pdf

Skakun, O. (2001). Theory of State and Law: textbook. Kharkiv: Konsum.

Zabroda, D. (2013). Administrative and legal principles: the essence and content of the category. Scientific and practical journal of Taras Shevchenko Ntional University of Kyiv, No. 2, pp. $45 \quad-\quad 51$. http://webcache.googleusercontent.com/sear ch?q=cache:uEaQG35rb7EJ:applaw.net/inde x.php/journal/article/download/557/492/+\&c $\mathrm{d}=1 \& \mathrm{hl}=\mathrm{ru} \& \mathrm{ct}=\mathrm{clnk} \& \mathrm{gl}=\mathrm{ua}$

Zakharova, V. and Filipova, V. (2013). Fundamentals of information and analytical activities. Kyiv: Publishing House "Center of Educational Literature". 